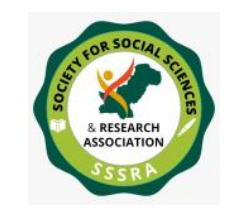

Pak. Journal of Int'L Affairs, Vol 3, Issue 2 (2020) Different Reporting Styles of Similar News ...

\title{
Different Reporting Styles of Similar News: Comparative Study of Two Urdu Newspapers Headlines
}

\author{
Kausar Rahmati Khan \\ Research Scholar \\ Department of Mass communication, \\ Federal Urdu University of Arts Science \& Technology, Karachi. \\ kausarrahmatikhan@gmail.com \\ Dr. Masroor Khanam \\ Incharge MPhil/Ph.D. Program \\ Department of Mass communication, \\ Federal Urdu University of Arts Science \& Technology, Karachi. \\ masroor.khanam@fuuast.edu.pk
}

\begin{abstract}
This research explains the reporting style of two newspapers of similar news items. It is related to the headlines styles of reporting in print media. Print media plays very strong role in present era, it's very important to know how media reveal same news in different point of views. This research paper investigates the news headlines through critical discourse analysis, of 2 daily Urdu newspapers correspondingly from First April to 7th April 2020. In this research paper COVID19 (Corona virus) news headlines were examine in two Urdu Newspapers Daily Jang newspaper and daily Express Newspaper. Newspapers of one week were examined for this research. The Daily Jang based in Karachi. Since 1939 is the oldest newspaper of Pakistan and continuously in publication. The Daily Jang newspaper is published by the Jang Group of Newspapers. The Daily Express is one of Pakistan's most broadly circulated Urdu Newspapers. Through Critical Discourse Analysis it was analyzed that the headlines in both the newspapers have different style of text, meaning and ideology because Jang and Express Newspapers have much difference in polices and in ideology.
\end{abstract}

Key Words: news headlines, The Daily Jang Urdu newspaper, The Daily Express newspapers, COVID-19, corona virus 


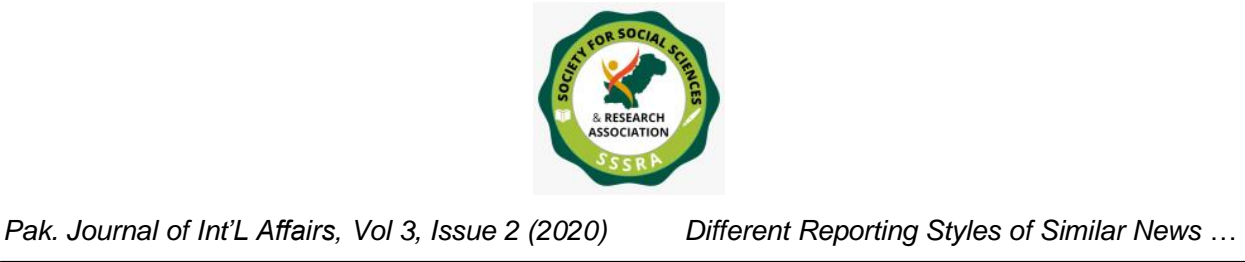

\section{Introduction}

The beginning of year 2020 has put the entire world in a problem like a war against a pandemic. The COVID-19 pandemic in Pakistan is part of the present pandemic of corona virus disease 2019 (COVID-19) severe acute respiratory syndrome is caused corona virus 2 (SARS-CoV-2). Now world is called as pre post COVID-19 and post COVID-19.

On 12 January 2020, the World Health Organization (WHO) established that a novel corona virus was the reason of a respiratory illness in a group of individuals in Wuhan City, Hubei Province, China, it was reported to the WHO on 31 December 2019. On 2 March the fifth case was reported, of a 45-year-old woman from Gilgit-Baltistan, who had too travelled from Iran.

The virus reached Pakistan on 26 February 2020. It was known when two cases were recorded in Pakistan, a student of Karachi University in Karachi returned from Iran and one more person in the Islamabad. On 18 March 2020, cases had been recorded in all four provinces of Pakistan. During 17 June, each region in Pakistan had recorded at least one confirmed case of COVID-19. This research discusses the function of media in using, operating and employing the pandemic in Pakistan. The chief focal point of this study is to comprehend and assess the reporting of COVID- 19 news in two Urdu Newspapers.

News of COVID-19 and lockdown has been published in newspapers daily since February, 2020.

\section{Aims and Objectives}

1. To observe the style of news of COVID-19 headlines in two Urdu newspapers.

2. To compare style of news headlines about COVID-19 (pandemic) between two Urdu newspapers

The media is supposed to play a helpful role in boosting the confidence of the nation during these distressing conditions ethically. The main objective of this research paper is to analyse the news headlines by critical discourse analysis. The Comparison between two Urdu Newspapers, The Daily Jang newspaper and the daily Express newspaper from first April 2020 to 7th April 2020 discussed in this research paper.

Language is the important feature of news. Newspapers are a very strong print media to provide information on social and national issues and create awareness about world issues to the society. This study focuses on news headlines because they are significant in creating the ideas of public and another point of the study is to draw attention to the differences in the style of the same news through different point of views. 


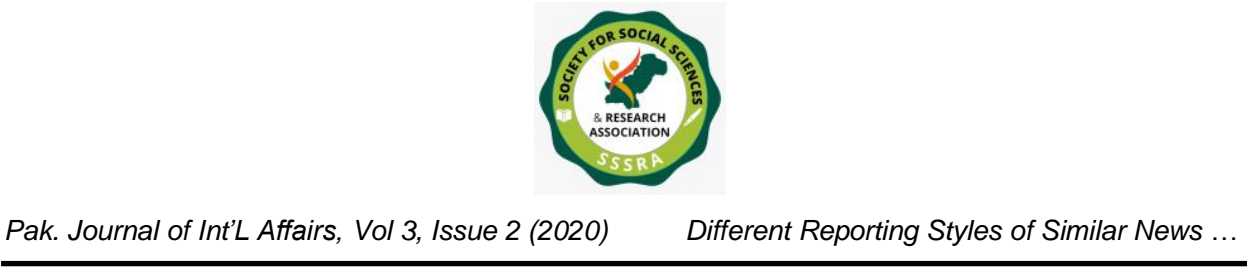

\section{Literature Review}

Newspapers report the same event in different approaches by operating headlines. The headlines in newspapers boost or lessen news value of every occurrence or event. It focuses on the problem of different newspapers use headlines purposely to control the incidents. Different news papers represent same events in different styles. The obvious motive for using diverse linguistic and background techniques is to attract masses, public.

Duanprakhon (2012) examined the language which is used in the front page headlines of newspapers in Thailand. Mardhyarini and Ariyanti (2016) conducted research to explore Headline News in newspapers. According to them the newspaper writes about all the news in active voice. Headlines are the most important part of newspaper. It is the first item that can grasp the mind of reader. The chief title of newspaper is generally on the first page of a newspaper as a rule printed in bold headlines, and they simplify the key points of the news. The titles are always positioned above news story in font.

According to Van Dijk (1995), ultimate features of news headlines is to believe the information of the most important and obvious event by the journalist. Ungerer (2000) said that the spirit of a complex story is a hard thing. This increases the curiosity of a reader. According Taiwo (2007: 324), strategic titles are used by in headline by the journalists and publishers. Emotional language and expressions in writing are used to attract the readers.

Newspapers headlines play a significant role in newspapers to attract readers. A significant message to readers is communicated through the news headlines. According to Develotte et al. (2001) societal, nationwide and educational demonstrations are publicized through headlines. It is believed that Headlines attract a large readership because most of the people buy newspapers only to read headlines. Significance of Headlines cannot be ignored because it should be so attractive and informative to attract and increase the readership.

The headline is the most important component or substance of newspaper. Headlines can be scanned by the readers. The news headlines are the outline of the event or story (Reah, 1998, p. 14). Lexical words are more valuable in headlines than grammatical words which are the reason of uncertainty in various cases. According to Ghannam, (2011) A headline can even so often inhabit additional space than the news itself, because it's printing is large and bold.

Mardh, (1980) explained that headline should be short that it can be read speedily but it should present particulars in detail. According to Mardh (1980), the normal size of headline in 


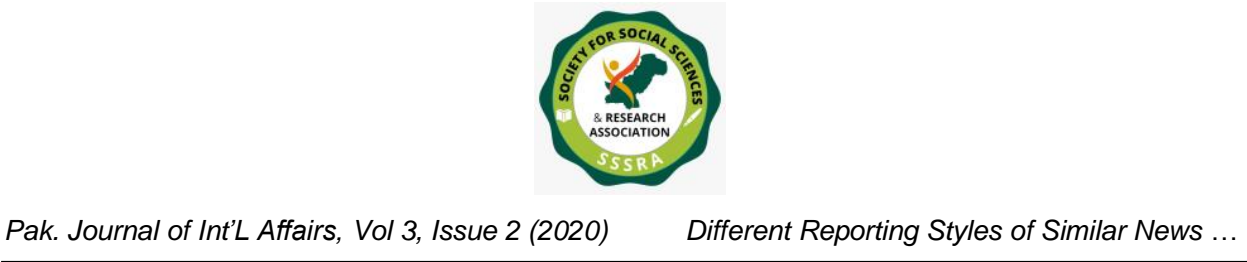

newspaper should be seven words. Selections of Lexical items in the headlines express assessment of the writer's estimation reasons. Subsequently, the choice of language is called the manifestation of thought and ideas of writer. So, it can be said that choice of words or language plays important role in writing headlines.

\section{Research Methodology}

Qualitative research method was used to collect and analyze the data for this research. Two Urdu newspapers headlines were selected, the Jang and The Express newspapers from First April to 7th April 2020, front pages headlines of Covid 19 were collected. These newspapers were selected through convenient sampling technique. Newspaper headlines were collected through purposive sampling techniques. The objective of this research is to find out the different demonstration of the same news in two Urdu newspapers headlines, consequently the data was analyzed through Van Dijk's method of media text analysis of critical discourse analysis and the headlines were categorized according to their types. The ideological differences in headlines of two Urdu newspapers were analyzed.

\section{Data Analysis}

\section{Headlines}

\section{Classification of news headlines}

Three types of headlines were observed in these two Urdu newspapers front pages, the Jang and The Express newspapers from First April to 7th April 2020. News of COVID 19 was observed.

\section{Plain Headlines}

Plain headlines are defined as the straightforward reports about any incident in newspapers. Through Critical Discourse Analysis researcher finds the concealed meaning and editor's ideological point of view. The writing which is used for media discourse actually seems easy but it always hold multifaceted ideological viewpoint. The following headlines are news of COVID 19 has been mentioned in two newspapers. The general word is COVID 19 and the entire situation is written in an easy and plain style.

\section{The Daily Jang Newspaper \\ 1. The Daily Jang Newspaper 1st April, 2020, Front Page \\ Corona marezon $\sim$ ki Taadad men $\sim$ record Izafa \\ (A record increase in the number of coronary patients)}




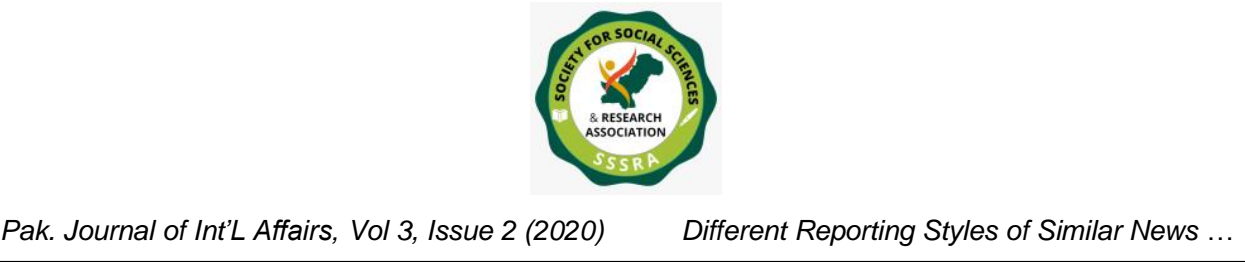

\section{The Daily Jang Newspaper 2nd April, 2020, Front Page}

Corona 206 Mumalik tak phel gaya halakaten $\sim 46$ hazar se baRh Gayen mareezon ki taadad 9 lakh (Corona has increased about 206 countries, more than 46 thousands died, 900,000 patients)

3. The Daily Jang Newspaper 3rd April, 2020, Front Page

Corona ke paishe nazar muqaddas maqamat per saxt hifazati iqdamat Jadda aur Riaz as men bhi daxle per pabandi he.

(Security measures due to corona at holy sites in Jeddah and Riyadh are also prohibited.)

\section{The Daily Jang Newspaper 4rth April, 2020, Front Page}

14 April se Tamirat aur mutalliqa shobon ka lock down gher moasser .

(Since 14 April lockdown on construction and other fields is not effective

\section{The Daily Jang Newspaper 5th April, 2020, Front Page}

Corona virus; Aata Buran baqayda mansoba bandi se Paida Kiya Gaya. Corona virus: (Shortage of flour has been done through planning )

6. The Daily Jang Newspaper 6th April, 2020, Front Page

28 din ke liye lockdown yaqini banaen

(Lockdown should be imposed for 28 days)

7th The Daily Jang Newspaper First April, 2020, Front Page

Wazeere Azam ka action shoro berterfian kaabeena men

(Changes in the parliament Prim minster's action begins)

\section{Critical Data Analysis}

As it is cleared that the Plain headlines are defined as the simple reports about any incident in newspapers. The headlines of news of COVID 19 have been mentioned in two newspapers. The general word is COVID 19 and the entire situation is written in an easy and plain style. The above mention headlines of The Daily Jang newspaper of seven days from first April 2020 to 7 th April 2020 are simple statement of daily incidents of COVID 19. Language is simple. Lengthy news is found in this newspaper.

\section{The Daily Express Newspaper}

1. The Daily Express Newspaper 1st April, 2020, Front Page

Exporter's ka Mal na rokane ki Hidayat

(Instructions not to stop the goods of exporters')

2. The Daily Express Newspaper 2nd April, 2020, Front Page

Expo centre Men 1000 bistaron Ka field hospital taiyar 
(1000 beds field hospital is ready at Expo centre)

3. The Daily Express Newspaper 3rd April, 2020, Front Page

Corona: 34 afrad janbaaq

(Corona: 34 died)

4. The Daily Express Newspaper 4rth April, 2020, Front Page

Namaze juma ke duran mukammal lockdown

(Complete lockdown during Namaze Juma)

\section{The Daily Express Newspaper 5th April, 2020, Front Page}

Corona Jung xatm nahi hogi

(Corona war will not be end)

\section{The Daily Express Newspaper 6th April, 2020, Front Page}

Pakistan men corona ka phelao sust he

(Spread of Corona in Pakistan is slow)

\section{The Daily Express Newspaper 7th April, 2020, Front Page}

Corona per Hukumat sirf meeting kar rahi hai Amali kam Kuchh Nahin

(Government is busy in meetings for corona and no practical work)

\section{Critical Data Analysis}

As it is cleared that the Plain headlines are defined as the simple reports about any incident in newspapers. The headlines of news of COVID 19 have been mentioned in two newspapers. The general word is COVID 19 and the entire situation is written in an easy and plain style. The above mention headlines of The Daily Express newspaper of seven days from first April 2020 to 7th April 2020 are simple statement of daily incidents of COVID 19. Language is simple and statements are short. 


\section{Table 1}

\begin{tabular}{|c|c|c|c|c|c|}
\hline S.N & & Plain Headlines & & Same & Different \\
\hline & & The Daily Jang Newspaper & The Daily Express Newspaper & & \\
\hline 1 & 1.4 .2020 & $\begin{array}{l}\text { Corona marezan } \sim \text { ki Taadad men } ~ \\
\text { record Izafa }\end{array}$ & Exporter's ka Mal na rokane ki Hidaxat & No & Yes \\
\hline 2 & 2.4 .2020 & $\begin{array}{l}\text { Corona } 206 \text { Mumalik tak phel gaxa } \\
\text { halakaten } 46 \text { hazar se baRh } \\
\text { Gayen mareezon } \sim \text { ki taadad } 9 \text { lakh }\end{array}$ & $\begin{array}{l}\text { Expo centre Men } 1000 \text { bistaren } \sim \mathrm{Ka} \\
\text { field hospital taixar }\end{array}$ & No & Yes \\
\hline 3 & 3.4 .2020 & $\begin{array}{l}\text { Corona ke paishe nazar mugaddas } \\
\text { magamat per saxt hifazati igdamat } \\
\text { Jadda aur Riaz as men bhi daxle } \\
\text { per pabandi he. }\end{array}$ & Corona: 34 afrad janbaag & No & Yes \\
\hline 4 & 4.4 .2020 & $\begin{array}{l}14 \text { April se Tamirat aur mutalliga } \\
\text { shobon ka lock down gher } \\
\text { moasser. }\end{array}$ & $\begin{array}{l}\text { Namaze juma ke duran mukammal } \\
\text { lockdown }\end{array}$ & No & Yes \\
\hline 5 & 5.4 .2020 & $\begin{array}{l}\text { Corona virus; Aata Buran bagaxda } \\
\text { mansoba bandi se Paida Kiya Gaya. }\end{array}$ & Corona Jung xatm nahi hogi & No & Yes \\
\hline 6 & 6.4 .2020 & $\begin{array}{l}28 \text { din ke live lockdown yagini } \\
\text { banaen }\end{array}$ & $\begin{array}{l}\text { Pakistan men corona ka phelag sust } \\
\text { he }\end{array}$ & No & Yes \\
\hline 7 & 7.4 .2020 & $\begin{array}{l}\text { Wazeere Azam ka action shore } \\
\text { berterfian } \text { kaabeena men }\end{array}$ & $\begin{array}{l}\text { Corona per Hukumat sirf meeting kar } \\
\text { rahi hai Amali kam Kuchh Nahin }\end{array}$ & No & Yes \\
\hline
\end{tabular}

\section{Speech as Headlines}

Direct speech of the person is used in this headline and names of narrator are too declared through this news become more authentic.

\section{The Daily Jang Newspaper 1st April, 2020, Front Page}

Aate O digar asiya ki qillat aur qimat par Nazar Rakhi Jaaye ; Imran Khan 
(Watch the scarcity of food and price of food; Imran Khan) Opposition leader gareebano Men Jhanki aur apne Assasse ka Kuchh hissa wazeera Azam fund men Jama karaen Firdaus Ashiq Avan

(Opposition leaders "peeks in" and "contributes some of their assets to the Prime Minister's Fund" ;Firdaus Ashiq Avan)

\section{The Daily Jang Newspaper 2nd April, 2020, Front Page}

a virus ko Pakistan men BaRhana He Sharah ka pata nahin Eehtiayat Nia ki to tadad 50 se zyada ho sakti he; Imran Khan na virus will increase in Pakistan, percentage is not known, cautions are not taking then toll will raise more than 50 housands; Imran Khan)

\section{The Daily Jang Newspaper 3rd April, 2020, Front Page}

Namaz ghar par Ada Karen Islami Nazriyati Council

(Pray at home; Islamic Ideology Council)

\section{The Daily Jang Newspaper 4rth April, 2020, Front Page}

Jahan awam ke Jama hone ka xadsha he vahan mukmmal lock down Kiya gaya hai, Wazir Azam (There is a complete lock where people can gather, Prime Minister)

\section{The Daily Jang Newspaper 5th April, 2020, Front Page}

Virus kab xatm Hoga pata nahin Pakistan Jaise Taraqqi pazir mulk ka kya hal hoga, Wazir E Azam

(We don't know when the virus will end. What will be the solution for a developing country like Pakistan? Prime Minister)

\section{The Daily Jang Newspaper 6th April, 2020, Front Page}




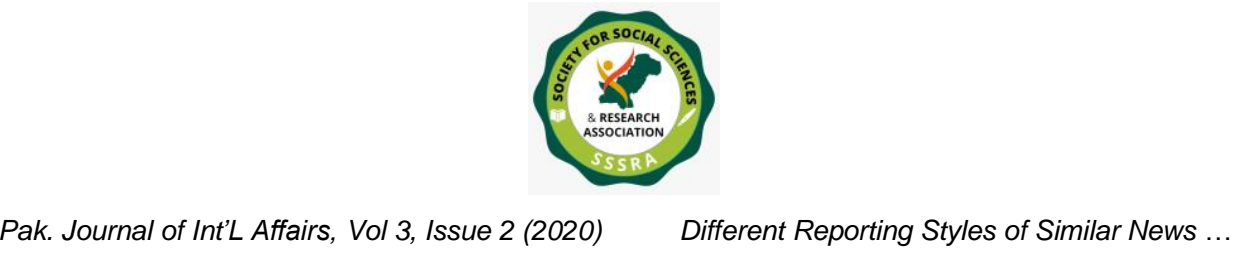

14 April Tak lockdown kamyab Banaya Tu vaBa kam karne men Kamyab Ho jaen ge ; Wazir Aala Sindh

(If lockdown imposed till 14th April then we will be able to control the pandemic; chief Minister Sindh)

\section{7th The Daily Jang Newspaper First April, 2020, Front Page}

Har hospital, clinic laazimi khula rehna chaheye , Supreme Court

(Every hospital and clinic should be opened, Supreme Court)

\section{Critical Discourse Analysis}

Direct speech of the person is used in this headline and names of narrator are too declared through this news become more authentic. Most of the news in Jang newspaper in all seven days related to COVID 19 and related to statements, in Jang newspaper of narrator is mentioned in direct speech especially on front page there are statements of prime minister and politicians. Its ideology is based on coverage of important event of national and international.

Jang is a national newspaper; presents a blend of major news and individual impact sections. During the week, the foremost pages publish national and international news, business and finance, comments and analysis, interviews, entertainment and daily sports reporting.

\section{The Daily Express Newspaper}

\section{The Daily Express Newspaper 1st April, 2020, Front Page}

Exporter's ka Mal na rokane ki Hidayat, wifaqi kabeena (Instructions not to stop the goods of exporters') wifaqi kabeena

\section{The Daily Express Newspaper 2nd April, 2020, Front Page}

Expo centre Men 1000 bistaron Ka field hospital taiyar; Bazdar

(1000 beds field hospital is ready at Expo centre; Bazdar)

\section{The Daily Express Newspaper 3rd April, 2020, Front Page}




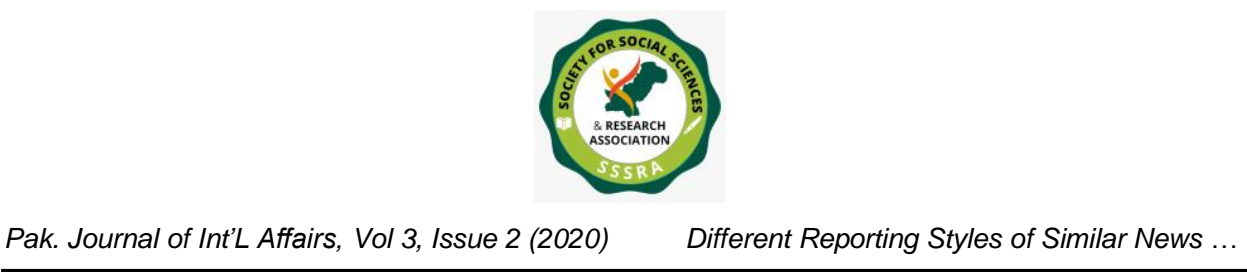

Corona: 34 afrad janbaaq, mutassereen ki taadad 2386 ho gaye ; Chief Minister

(Corona: 34 died infected are 2386; Chief Minister)

\section{The Daily Express Newspaper 4rth April, 2020, Front Page}

Punjab men rashan ki taqseem shoro, hum daave nahi ker te; Wazeere Aala

(Distribution of food has began in Punjab, chief Minister)

\section{The Daily Express Newspaper 5th April, 2020, Front Page}

Corona Jung xatm nahi hogi BaRe Mulk Himmat Haar Gaye ham ko vaba aur Bhookh donon se laRna he; Wazire Azam

(Corona war will not be end big countries are losing hope we have to fight with pandemic and hunger both, Prime Minister)

\section{The Daily Express Newspaper 6th April, 2020, Front Page}

Lockdown se corona men kami aye, Asad Umer

(Corona has decreased through Lockdown, Asad Umer )

\section{The Daily Express Newspaper 7th April, 2020, Front Page}

Corona per Hukumat sirf meeting kar rahi hai Amali kam Kuchh Nahin; Chief Justice

(Government is busy in meetings for corona and no practical work; Chief Justice)

\section{Critical Discourse Analysis}

Direct speech of the person is used in this headline and names of narrator are too declared through this news become more authentic. The news in Express newspaper in all seven days related to COVID 19 and related to statements are less than the Jang newspaper. 
Table 2:

\begin{tabular}{|c|c|c|c|c|c|}
\hline $\begin{array}{l}\mathrm{S} . \\
\mathbf{N}\end{array}$ & Date & Speech as Headlines & & Same & Different \\
\hline - & & The Daily Jang Newspaper & The Daily Express Newspaper & & \\
\hline 1 & 1.4 .2020 & $\begin{array}{l}\text { Aate O dizar agiva ki gillat aur } \\
\text { gimat par Nazar Rakhi Jaaxe: } \\
\text { Imran Khan }\end{array}$ & Exporter's ka Mal na rokanes ki Hidaxat, wifarai babeena & No & Yes \\
\hline 2 & 2.4 .2020 & $\begin{array}{l}\text { Corona virus ko Pakistan men } \\
\text { BaRhana He Sharah ka pata } \\
\text { nahin Behtiayat Nia ki to tadad } \\
50 \text { bavar, se zxadda ho galti he; } \\
\text { Imran Khan }\end{array}$ & $\begin{array}{l}\text { Expo centte Men } 1000 \text { bistaroor Ka field hospital taixar: } \\
\text { Bazdar }\end{array}$ & No & Yes \\
\hline 3 & 3.4 .2020 & $\begin{array}{l}\text { Namazz ahar par Ada Karem } \\
\text { Islami-Nazrivati Council }\end{array}$ & $\begin{array}{l}\text { Corona: } 34 \text { aftad janbaag, mutasserreen ki taadad } 2386 \text { ho gaxe- } \\
\text { Chief Minister }\end{array}$ & No & Yes \\
\hline 4 & 4.4 .2020 & $\begin{array}{l}\text { Jahan awam ke Jama hone ka } \\
\text { xadsha he yahan mukpmomal lock } \\
\text { down Kiya gava haj, Wazir Azam }\end{array}$ & $\begin{array}{l}\text { Punjab men rashan ki taqseem shorr, hum daave nahiker te: } \\
\text { Whazeere Aala }\end{array}$ & No & Yes \\
\hline 5 & 5.4 .2020 & $\begin{array}{l}\text { Virus bab satm Hoga pata vahin } \\
\text { Pakistan Jaige Taragai pazjis mullk } \\
\text { ka bxa bal hoga, Wazir E Azam }\end{array}$ & $\begin{array}{l}\text { Corona Jung zatm nahi hogi BaRe, Mulk Himmat Haan Gaye } \\
\text { ham ko yaba aur Bhoskh donon se laRna he; Wazire Azam }\end{array}$ & No & Yes \\
\hline 6 & 6.4 .2020 & 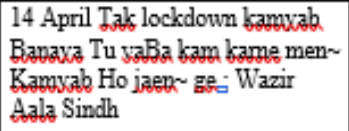 & Lockdown se corona men kami aye, Asad Umer & No & Yes \\
\hline 7 & 7.4 .2020 & $\begin{array}{l}\text { Har hospital, clinic lazaimi khula } \\
\text { rebna chaheve. Supreme Court }\end{array}$ & $\begin{array}{l}\text { Corona per Hukumat giff meeting kar rabi bai Amalikam. } \\
\text { Kuchh Nahin: Chief Juetice }\end{array}$ & No & Yes \\
\hline
\end{tabular}

\section{Headlines with Pointers}

These types of news headlines include two parts. First part includes introduction of the news 


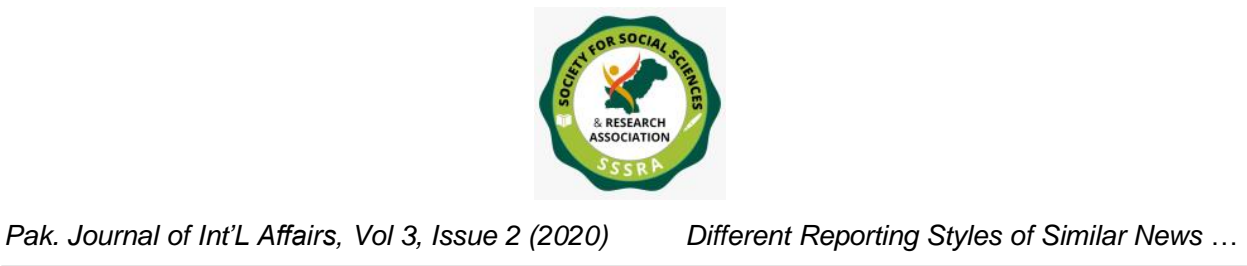

statement, and in the second part ideologies of the editors can be mentioned.

\section{The Daily Jang Newspaper 1st April, 2020, Front Page}

Mazid 3 jane nigal gaya taaadad 26 ho gayi mushtaba mareez 15709 mussedeqa 2033 ho gaye Punjab men bhi Sind ki tarah lock down

(More 3 Swallowed, number raised to 26, suspected patients 15709, confirmed 2033; lockdown has imposed in Punjab like Sind)

Sind men do Halakaten 24 ghante Men 110 izafa Punjab Men dukan jald band hongi rawind seal , ko bhi Ghar Sese nahi nikalega kaga Rangers ka Gasht

(Two deaths in Sindh within 24 Hours, 110 Increase, Shops will be closed early, Riwind sealed, no one will be allowed to come outside; Rangers will be patrolling around)

\section{The Daily Jang Newspaper 2nd April, 2020, Front Page}

Amwat Sind aur Panjab men hoen ,Karachi men 33, mulk bher men 86, Naey cases ka izafa, 94 mareez sehatyab.

(Deaths reported in Sind and Punjab, Karachi 33, across the country 86 new cases, 94 patients recovery.)

\section{The Daily Jang Newspaper 3rd April, 2020, Front Page}

Corona abadion ko nigalne laga Europe aur America men tabahi , Pakistan per bhi war teze (Corona has began to swallow up populations; destruction in Europe and America; Pakistan is in danger zone)

\section{The Daily Jang Newspaper 4rth April, 2020, Front Page}

coronavirus; Al ami maeshat ko 683 k harab rupe ka nuqsan Pakistan ki Sharh 2.4 se kam hokar 1.1 ho sakti he.

(coronavirus; world economy has lost 683 billion, Pakistan's percentage can be decreased from 2.4 to 1.1 ) 


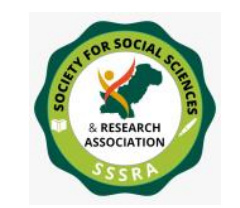

Pak. Journal of Int'L Affairs, Vol 3, Issue 2 (2020)

Different Reporting Styles of Similar News ...

\section{The Daily Jang Newspaper 5th April, 2020, Front Page}

Pakistan men Corona cases 25 April Tak 50,000 pahunchne ka xadsh. (Corona cases could be increased 50,000 from 25th April)

\section{The Daily Jang Newspaper 6th April, 2020, Front Page}

naye cases ki tadad 389 ho gai 190 mareez Sehat yab.

(News cases are 389, 190 patients cured)

\section{7th The Daily Jang Newspaper First April, 2020, Front Page}

Wifaqi eqdam se Mutmein Afrad ki sharah men 17 fisad izafa 78 fisad Pakistani subon se mutmaen

(17 percent people are satisfied with federal government's actions, 78 percentprovinces are satisfied)

\section{Critical Discourse Analysis}

These types of news headlines include two parts, First part includes introduction of the news statement, and in the second part ideologies of the editors can be mentioned. In all above news it is very clear that Jang newspaper ideology related to corona is helpful to the public because with the corona news its causes, treatments, deaths newspaper is providing information about the precautions some hope and describing economical, mental, social condition of the society of Pakistan and world as well

\section{The Daily Express Newspaper 1. The Daily Express Newspaper 1st April, 2020, Front} Page Corona; 26 Afrad Janbahaq mutasereen 2025 Ho Gaye 58 se Hatyab

(Corona; 26 people died, infected 2025, 58 cured)

\section{The Daily Express Newspaper 2nd April, 2020, Front Page}

Expo centre Men 1000 bistaron Ka field hospital taiyar, tibbi amla qabile tehseen he; Bazdar (1000 beds field hospital is ready at Expo centre, medical staff appraisable ; Bazdar) 


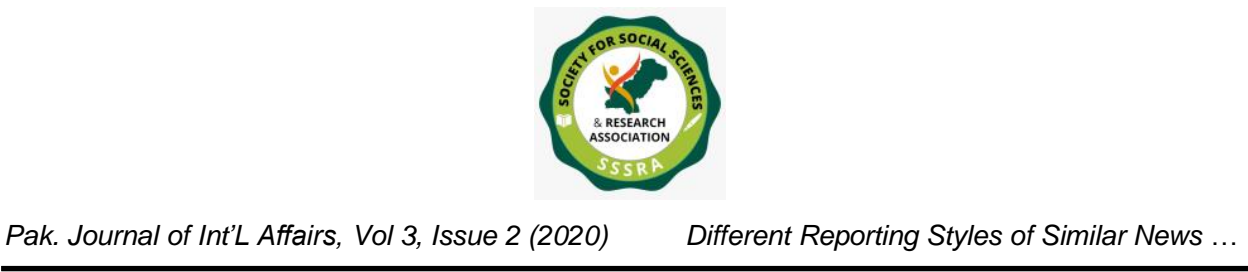

\section{The Daily Express Newspaper 3rd April, 2020, Front Page}

Corona: 34 afrad janbaaq, mutassereen ki taadad 2386 ho gaye, 107 sehatyab .

(Corona: 34 died infected are 2386, 107cured)

\section{The Daily Express Newspaper 4rth April, 2020, Front Page}

Corona: 2396 janbahaq hone walon ki taadad 40 hogaye , 127 sehatyab

(Corona: 2396 died, number of dead increased 40, 127 cured)

\section{The Daily Express Newspaper 5th April, 2020, Front Page}

Textile, Sports, pharmacy 8 sanaton ko chalane ki mashroot Ijazat ; notification jari

(Textile, Sports, pharmacy 8 industries have permission to reopen, notification)

\section{The Daily Express Newspaper 6th April, 2020, Front Page}

Mustahiq xandanon ke liye 12000 rqam kerdi

(12000 rupees will be given to the deprived families)

\section{The Daily Express Newspaper 7th April, 2020, Front Page}

Hukumat ko paise ki Pari ya rashion Baant Ne per zor he, Subon ke pass kit hi Nahin

(Government is looking for money or distributing food and provinces have no kits)

\section{Critical Discourse Analysis}

These types of news headlines include two parts, First part includes introduction of the news statement, and in the second part ideologies of the editors can be mentioned. In all above news it is very clear that Express newspaper ideology related to corona is helpful to the public because with the corona news its causes, treatments, deaths newspaper is providing information about the precautions some hope and describing economical, mental, social condition of the society of Pakistan and world as well. 


\section{Table 3}

\begin{tabular}{|c|c|c|c|c|c|}
\hline \multirow[t]{2}{*}{$\overline{\text { S.No }}$} & \multirow[t]{2}{*}{ Date } & \multicolumn{2}{|l|}{ Headlines with Pointers } & \multirow[t]{2}{*}{ Same } & \multirow[t]{2}{*}{ Different } \\
\hline & & The Daily Jang Newspaper & The Daily Express Newspaper & & \\
\hline 1 & 1.4 .2020 & $\begin{array}{l}\text { Mazid } 3 \text { jane njagl gaxa taaadad } \\
26 \text { ho gaxi mushtaba mareez } \\
15709 \text { mustedega } 2033 \text { ho gave } \\
\text { Punjab men bhi Sind ki tarah } \\
\text { lock down }\end{array}$ & $\begin{array}{l}\text { Corona; } 26 \text { Afrad Janbahas } \\
\text { mutaseraen. } 2025 \text { Ho Gaye } 58 \text { se } \\
\text { Hatrak }\end{array}$ & No & Yes \\
\hline 2 & 2.4 .2020 & $\begin{array}{l}\text { Amurat Sind aur Panjab men } \\
\text { boegr Karachi men 33, mulk } \\
\text { bher, men 86, Naex cases ka } \\
\text { izaff, } 94 \text { mareaz gehatcab. }\end{array}$ & $\begin{array}{l}\text { Expo centre Men } 1000 \\
\text { bistaron Ka field hospital taixar. } \\
\text { tibbi amla gabile tebseen he; } \\
\text { Bazdar }\end{array}$ & No & Yes \\
\hline 3 & 3.4 .2020 & $\begin{array}{l}\text { Corona abadion ko nigalne laga } \\
\text { Europe aur America men tabahi } \\
\text { Pakistan per bhi war teze }\end{array}$ & 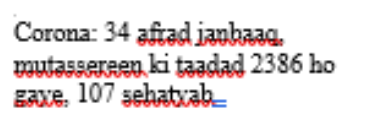 & No & Yes \\
\hline 4 & 4.4 .2020 & $\begin{array}{l}\text { coronavirus; } \mathrm{Al} \text { ami maeshat ko } \\
683 \mathrm{k} \text { harah rupe ka nugsan. } \\
\text { Pakistan ki Sharl. } 2.4 \text { se kam holkar } \\
1.1 \text { ho galti he. }\end{array}$ & $\begin{array}{l}\text { Corona: } 2396 \text { jazabahag hone } \\
\text { walon ki taadad } 40 \text { begaxe } 127 \\
\text { sehattrab. }\end{array}$ & No & Yes \\
\hline$\overline{5}$ & 5.4 .2020 & $\begin{array}{l}\text { Pakistan men Corona cases } 25 \\
\text { April Tak } 50,000 \text { pahumchne ka } \\
\text { xadsh. }\end{array}$ & $\begin{array}{l}\text { Textile, Sports, pharmacy } 8 \\
\text { sanatogn ko challane ki mashroot } \\
\text { Ljazat- notification jari }\end{array}$ & No & Yes \\
\hline 6 & 6.4 .2020 & $\begin{array}{l}\text { nawe cases ki tadad } 389 \text { ho gai } 190 \\
\text { mareez Sehat yak. }\end{array}$ & $\begin{array}{l}\text { Mustahiq xandangon ke lixe } \\
12000 \text { rgam kerdi. }\end{array}$ & No & Yes \\
\hline 7 & 7.4 .2020 & 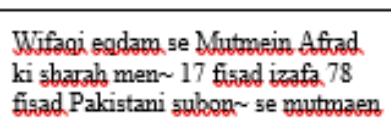 & $\begin{array}{l}\text { Hukurmat ko paise ki Pari ya } \\
\text { tashion Basant Ne per zor he, } \\
\text { Subog ke pass kit hi Nahin }\end{array}$ & No & Yes \\
\hline
\end{tabular}




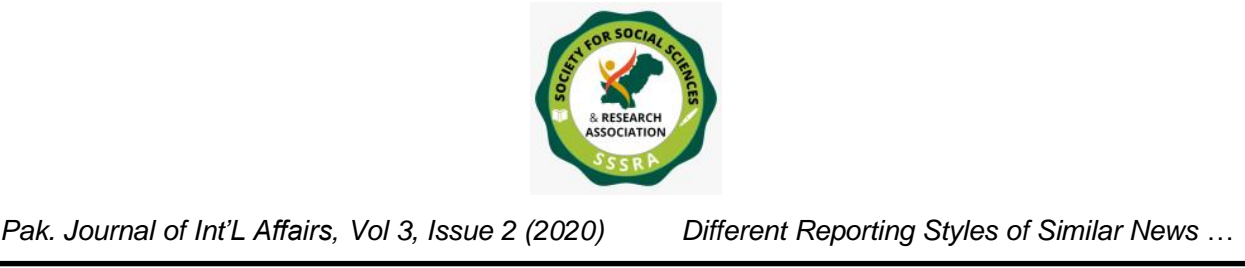

\section{Discussion}

News coverage related to COVID 19 is different in both the newspapers. Reason is COVID 19 is pandemic and like another part of the world, the media in Pakistan has responsibility that how to report the occurrence and impact of Covid-19. New challenges thrive for Pakistani media how to educate, inform and guide to the public for corona impacts. This task is very difficult and both the newspapers are trying to do their job with responsibility. The epidemic of coronavirus disease 2019 (COVID-19) has produced a worldwide health disaster it has had an unfathomable impact on the world and daily lives. It was a great job of print media to create awareness about the outbreak and its impact. Both the newspapers have tried to do the best job. The media in Pakistan has been dealing with limited policy situation and have restrictions to disclose current situations. News of corona covering by these newspapers is social, economical, educational and political style ids different of the same news.

\section{Conclusion}

News coverage related to COVID 19 is not same in both the newspapers. Reason is COVID 19 is pandemic and like another part of the world, the media in Pakistan has responsibility that how to report the occurrence and impact of Covid-19. A journalist duty is to provide the society and the government factual information. It is very important to comprehend the ideology of the newspaper is based on, professionalism and some other factors such as economic, social, political, cultural or governmental pressures. The analyzed newspapers of Pakistan selected due to various aspects of professionalism which was shown by through headlines of COVID 19 in pandemic situation of the world and country. Urdu newspapers deal with a much wider audience and it is clear that the Urdu headlines present more comprehensive description and focus on the ground realities and it is obvious that the Urdu headlines give more detailed description and focus on the actual realities. News headlines in both the newspapers have different style of text, meaning and ideology.

The present study highlighted the linguistic and contextual description of language used in newspapers headlines. Newspapers provide the same news in different styles by manoeuvring headlines. The headlines of newspapers enhance or reduce news value of every event. Different newspapers represent alike events in different ways. In the case of Jang and Express newspaper it has been clear that in same situation and same news of COVID 19, different headlines have been showing different polices and ideology of these newspapers. 


\section{References}

Arab News. 3 March 2020. Retrieved 4 March 2020

Develotte, C., \& Rechniewski, E. (2001). Discourse analysis of newspaper headlines: A methodological

Duanprakhon, P. (2012). Critical Discourse Analysis of News Headlines: A Case of Youth Crime in Thailand. School of Language and Communication National Institute of Development Administration in the Guardian and The Daily Telegraph. Surabaya: Unesa.

Elsevier. "Novel Coronavirus Information Center". Elsevier Connect. Archived from the original on 30 January 2020. Retrieved 15 March 2020.

Framework for research into national representations. Web Journal of French Media Studies, $4(1)$.

Ghannam, N. (2011). Newspaper ideology: A critical discourse analysis of an event published in six Lebanese ijel.ccsenet.org International Journal of English Linguistics Vol. 9, No. 1; 2019

Headlines. Nebula, 4(1),

John Benjamins. https://doi.org/10.1075/pbns.80

Mardh, I., (1980). Headlines: On the Grammar of English Front Page Headlines. Malmo.

Mardhyarini, M.R \& Ariyanti, L. (2016). Critical Discourse Analysis of the Headline News

Panic rises in Pakistan as country confirms fifth Coronavirus Case. BOL News. 3 March 2020. Retrieved 4 March 2020.

Reah, D. (1998). The language of newspapers. London: Routledge. 
Reynolds, Matt (4 March 2020). "What is coronavirus and how close is it to becoming a pandemic?". Wired UK. ISSN 1357-0978. Archived from the original on 5 March 2020. Retrieved 5 March 2020.

Taiwo, R. (2007). Language, ideology and power relations in Nigerian newspaper headlines. Nebula, 4(1)

The New York Times. Reuters. 2 March 2020. ISSN 0362-4331. Retrieved 4 March 2020.

Ungerer, F. (Ed.). (2000). English media texts past and present language and textual structure. Philadelphia, PA:

Van Dijk, T. A. (1995). Discourse as Structure and Process. London: Sage.

Van Dijk, T. A. (1998). Critical Discourse analysis. "Welcome to E-Commerce Times". Ecommerce times. 218-245.312 